\title{
Розвиток спортивних багатоборств в олімпійському спорті (на матеріалі сучасного п'ятиборства)
}

\author{
Юрій Павленко ${ }^{1}$, Микола Єгупов ${ }^{1}$, Володимир Бобр²
}

Національний університет фізичного виховання і спорту України, Київ, Україна ${ }^{2}$ Національний авіаційний університет, Київ, Україна

Анотація. Знання про тенденції розвитку спортивних багатоборств важливе для фрормування стратегії їх розвитку в країні та участі у діяльності міжнародних спортивних організацій. Мета. Визначити особливості розвитку та трансформації спортивних багатоборств в олімпійському спорті (на прикладі сучасного п'ятиборства). Методи. Аналіз та узагальнення спеціальної літератури і документальних джерел, порівняння, аналогії. Результати. Змагання, які вимагали прояву різних фізичних якостей під час виконання різнопланових технічних дій, мали велику популярність на різних етапах розвитку людства. 3 відродженням Олімпійських ігор одразу виникла ідея включити до їх програми спортивні багатоборства. На сьогодні існує багато видів змагань, де остаточний результат визначається за виступами у кількох видах спорту, дисциплінах. На прикладі сучасного п'ятиборства показано, як небезпека втратити статус олімпійського виду спорту через недостатню його популярність змусила міжнародну федерацію надати змаганням більшої динамічності та видовищності завдяки зменшенню їх тривалості; спрощенню системи визначення переможців, зрозумілої вболівальникам; локалізації місць проведення змагань; зрівнянню можливості спортсменів з різними провідними видами багатоборства стати переможцями; запровадженню змагань серед жінок; проведенню естафет, у тому числі змішаних за участю чоловіків та жінок; покращенню інформаційного забезпечення проведення змагань. Розвиток спортивних багатоборств слід розглядати як вагомий фрактор історичної спадкоємності і збереження традицій в олімпійському спорті, концепції фізично розвиненої людини. Спортивні багатоборства та комбіновані види змагань займають суттєве місце у програмі сучасних Олімпійських ігор. Збільшення конкуренції між різними видами спорту за потрапляння до програми Олімпійських ігор спонукають представників спортивних багатоборств робити їх привабливими для комерційних структур, засобів масової інформації та глядачів.

Ключові слова: Олімпійські ігри, багатоборства, історія, спадкоємність, транссрормація, тенденції.

\section{lurii Pavlenko, Mykola lehupov, Volodymyr Bobr}

\section{DEVELOPMENT OF ATHLETIC ALL-AROUND IN THE OLYMPIC SPORT (AS EXEMPLIFIED IN MODERN PENTATHLON)}

Abstract. Knowledge of the trends in the development of all-around sports is important for the formation of strategies for their development in the country and participation in the activities of international sports organizations. Objective. Identify the features of the development and transformation of all-around sports in Olympic sport (on the example of modern pentathlon). Methods. Analysis and generalization of special literature and documentary sources, comparisons, analogies. Results. Competitions that required the manifestation of different physical qualities during the performance of various technical actions were very popular at different stages of human development. With the revival of the Olympic Games, the idea immediately arose to include all-around sports in their program. Today there are many types of competitions, in which the final result is determined by performances in several sports events, disciplines. The example of modern pentathlon shows how the danger of losing the status of an Olympic sport due to its insufficient popularity has forced the international federation to give competitions more dynamism and entertainment by reducing their duration; simplification of the system of determining winners, understandable to fans; localization of competition venues; equating the ability of athletes with different leading types of all-around to become winners; introduction of competitions among women; conducting relay races, including mixed ones with the participation of men and women; improving the information support of the competition. The development of all-around sports

Pavlenko lu, lehupov V, Bobr V. Development of athletic all-around in the olympic sport (as exemplified in modern pentathlon). Theory and Methods of Physical education and sports. 2020; 3: 38-42

DOI: $10.32652 /$ tmfvs.2020.3.38-42 виток спортивних багатоборств в олімпійському спорті (на матеріалі сучасного п'ятиборства). Теорія і методика фрізичного виховання і спорту. 2020; 3 : 38-42

DOI: 10.32652/tmfvs.2020.3.38-42
Вступ. Розвиток видів спорту знаходиться у прямій залежності від їх представництва в олімпійській програмі. Кожна міжнародна спортивна фредерація намагається мати свою присутність у групі олімпійських видів спорту або визнаних Міжнародним олімпійським комітетом (МОК).

Протягом усього часу існування сучасних Олімпійських ігор у програмі були представлені спортивні багатоборства, які потрапляли або виключалися певною мірою стихійно і під впливом різних факторів. Уже багато років виникає питання виключення з програми Ігор Олімпіад сучасного п'ятиборства. Разом 3 тим, інший вид багатоборства дуже швидко, з часу його виникнення, потрапив до програми Ігор. Такий стан пов'язують 3 ігноруванням МOK історичної спадкоємності і збереження традицій у фрормуванні програми Олімпійських ігор під впливом комерційних або політичних сил $[4,8]$. Міжнародні спортивні федерації вимушені пристосовуватися до сучасних умов для запобігання виключення їхніх видів спорту з програми Олімпійських ігор. У науковому просторі представлено мало інформації про місце та значення спортивних багатоборств в історії олімпійського спорту [1, 16, 22]. Найбільшої трансформації в олімпійському спорті зазнала програма змагань у сучасному п'ятиборстві.

Дослідження тенденцій розвитку цього виду багатоборства безумовно слід розглядати через призму діяльності Міжнародного союзу сучасного п'ятиборства (МССП) під впливом внутрішніх та зовнішніх факторів олімпійського спорту. Нині це стає особливо актуальним, оскільки, з одного боку, політика МОК спрямована на скорочення учасників Ігор Олімпіад, а з іншого - на збільшення видів спорту, дисциплін, видів змагань у програмі Олімпійських ігор. 
should be considered as an important factor in the historical continuity and preservation of traditions in the Olympic sport, the concept of a physically developed person. Sports all-around and combined types of competitions occupy a significant place in the program of the modern Olympic Games. Increasing competition between different sports events for the Olympic Games encourages all-around sports to make them attractive to businesses, the media and spectators. Keywords: Olympic Games, all-around, history, succession, transformation, tendencies.

Знання про тенденції розвитку спортивних багатоборств можуть бути використані фрахівцями для формування стратегії їх розвитку в країні та політики участі своїх представників у діяльності міжнародних спортивних організацій.

Мета дослідження - визначити особливості розвитку та трансформації спортивних багатоборств в олімпійському спорті (на прикладі сучасного п'ятиборства).

Методи дослідження: аналіз та узагальнення спеціальної літератури і документальних джерел, порівняння, аналогії.

Результати дослідження та їх обговорення. Змагання, які вимагали прояву різних фрізичних якостей під час виконання різнопланових технічних дій, мали велику популярність на різних етапах розвитку людства.

$\begin{array}{ll}\text { Античний } & - \text { Давньогрецький пентатлон, } \\ & \text { змагання римських воїнів з } \\ & \text { квінтертіуму тощо } \\ \text { Серед- } & - \text { Випробування вікінгів, ли- } \\ \text { ньовіччя } & \text { царські турніри, комплекс } \\ & \text { вправ гомоуніверсале тощо } \\ \text { Новий } & - \text { Змагання норвезьких війсь- } \\ \text { час } & \text { кових гірськолижників, шкіль- } \\ & \text { не п'ятиборство Німеччини, } \\ & \text { п'ятиборство Олімпійських } \\ & \text { ігор Венлока, «змагання різ- } \\ & \text { носторонніх атлетів» США тощо } \\ \text { Новітній } & - \text { Сучасне п'ятиборство, лег- } \\ \text { час } & \text { коатлетичні десятиборство } \\ & \text { та семиборство, тріатлон, } \\ & \text { кінне триборство, гімнастич- } \\ & \text { не багатоборство, біатлон, } \\ & \text { лижне двоборство тощо }\end{array}$

Перша документована згадка про найдавніший вид багатоборства - пентатлон - належить до XXVIII Олімпійських ігор Стародавньої Греції 708 р. до н.е. [5]. За грецькою міфологією, винахід п'ятиборства приписують Ясону - герою давньогрецьких міфів, ватажку аргонавтів. Під час походу за золотим руном аргонавти прибули на острів Лемнос, де жили лише жінки. Цариця Гіпсіпіла хотіла напасти на них зі зброєю, але її переконали прийняти їх з миром. На честь прибуття героїв Гіпсіпіла заснувала змагання з пентатлону. Переможцем змагань став Пелей, друг Ясона, син царя острова Егіна в Егейському морі [13]. Інша згадка стосується міфічного героя Персея, який, згідно з пророцтвом оракула, під час метання диска у змаганнях 3 п'ятиборства випадково вбив Акрісія, царя Аргоса і Мікен [14].

Пентатлон включав п'ять видів змагань: біг; стрибок у довжину з кам'яними або металевими гантелями в руках у супроводі музики; метання кам'яного, бронзового або залізного диска, масою більше 4 кг; метання списа на дальність та точність; боротьбу. Змагання проходили в один день і часто закінчувалися уночі. Послідовність виступів у різних видах змагань невідома, хоча найбільш вірогідною вважається така: біг, метання одного із снарядів, стрибки, метання іншого снаряда, боротьба. Точно не визначено програму змагань у кожному виді багатоборства. Спортсмени мали пробігти один стадій (стадіодром, 192 м) або, за іншою версією, п'ять стадіїв. П'ять разів пентатлоністи метали снаряд, де враховували найкращу спробу. Також вони робили п'ять спроб у стрибках у довжину, хоча $є$ інша думка, що атлети робили п'ять послідовних стрибків 3 місця, враховуючи їх результати - близько 15 м. У боротьбі також відбувалося п'ять поєдинків. $€$ суперечки щодо системи визначення переможця. Одні дослідники вважають, що використовувалась система підрахунку очок за виступи у кожному виді багатоборства, другі - що переможцем був той, хто вигравав три види змагань з чотирьох, а якщо такого атлета не було, два найкращих боролися, інші - що, спортсмени змагалися за олімпійською системою по парах, поки не залишались два атлети, які і виборювали чемпіонство [11, 16, 18, 19].
Пентатлоністи, які мали різноманітні навички, були у великій пошані, і розглядалися як взірець гармонійної фізично розвиненої людини. Давньогрецький фрілософ Аристотель (384322 до н. е.) так писав про спортсменів, які виступали у змаганнях 3 пентатлону: «У кого швидші та витриваліші ноги - той бігун; у кого вистачить сил, щоб стиснути в обіймах суперника, - той борець; а хто може вразити суперника потужним ударом - той кулачний боєць; ну а той, хто майстер у всьому - той бере участь у п'ятиборстві»; «тіло, здатне переносити всі зусилля, або на іподромі, або тілесної сили ... Ось чому спортсмени у п'ятиборстві $є$ найкрасивішими» [12].

Свідченням високої популярності пентатлону $є$ наявність малюнків 3 фрагментами змагань на багатьох керамічних речах того часу.

Хоча із занепадом грецької культури Олімпіади не проводились, змагання $з$ багатоборств мали місце у Римській імперії. Серед римських воїнів були поширені змагання з квінтертіуму, які включали плавання, кінні перегони, біг, боротьбу, метання диска. В епоху вікінгів (близько 800-1250рр.) нормани мали пройти ряд атлетичних випробувань: біг, боротьбу, метання важких списів і метання по рухомих веслах.

у Середні віки лицарі перевіряли свої навички у турнірах, де використовували систему підрахунку очок. Кандидати у лицарі проходити багатоденні тести і мали добре володіти численними фрізичними і бойовими навичками. Наприклад, у Франції X-XI ст. вони повинні були опанувати сім навичок: верхова їзда, фехтування, стрільба з лука, плавання, боротьба, мисливство та гра на лютні [22].

В епоху Відродження (XIV-XVI ст.) в Італії було сформовано ідею гармонійного удосконалення людини - гомоуніверсале. Обов'язковими руховими навичками цих людей були: верхова їзда, фехтування, стрільба з лука, біг та бокс. Згідно з трактатами про освітню ресорму в середині XVI ст., юнаки повинні були знати, як їздити у доспіхах на коні, займатися важкою атлетикою, бігати, боротися та стрибати у довжину та висоту. 
Популярними багатоборства залишились і у Новому часі. Змагання військових норвезьких гірськолижних полків включало лижні перегони зі стрільбою з гвинтівки. У 1767 р. на шведсько-норвезькому кордоні прикордонники змагалися у спуску на лижах зі схилу, намагаючись влучити з рушниці у ціль. У середині 1700-х років у Дессау (Німеччина) студенти змагалися у шкільному п'ятиборстві, яке поєднувало давньогрецьку версію та навички лицарства. У 1792 р. в Стокгольмі (Швеція) «загальний» чемпіон визнавався за результатами у трьох видах змагань: біг, кидання великого каменя, плавання. Наприкінці XVIII ст. німецький педагог Йоганн Крістоф Фрідріх Гутсмус щотижня учням нараховував бали за виступи у бігу, ходьбі та плаванні. Його ініціативу з формування легкоатлетичного десятиборства підтримали німецькі реформатори XIX ст., розпочавши «рух тернера» (гімнастика в унісон) [21, 22].

У XIX ст. почалися відроджуватися різні версії комплексних змагань. у Норвегії стали проводитися змагання 3 біатлону серед солдат. у Швейцарії з 1832 р. почали поширюватися змагання 3 багатоборств 3 різними варіантами фрізичних вправ: вільні вправи - підняття каменя - кидання каменя - стрибки - боротьба; вільні вправи - вправи на перекладині - на брусах - на коні - три види стрибків. У середині XIX ст. змагання з багатоборства проводилися в Ірландії. у 1851 р. до програми Олімпійських ігор, які організував доктор Вільям Брукс у містечку Мач Венлок (Велика Британія), було включено змагання 3 п'ятиборства: стрибок у висоту, стрибок у довжину, метання 36-фунтового каменя, біг на півмилі і лазіння по канату довжиною 55 футів. У 1880 р. на чемпіонаті Німеччини серед спортивних гімназій було проведено змагання 3 багатоборства, яке включало метання каменя, стрибок 3 жердиною та стрибок у довжину.

Популяризації комплексних змагань у США сприяло проведення Шотландських каледонських ігор, німецьких Тернерс та Ігор Американських коледжів. У цих змаганнях визначали «переможця багатоборця» - спортсмена 3 найбільшою кількістю медалей у різних видах змагань. У 1884 р. у США провели національний чемпіонат 3 багатоборства - «змагання різносторонніх атлетів». Спортсмени змагалися у десяти дисциплінах 3 п'ятихвилинним відпочинком між ними: біг 100 ярдів, стрільба, стрибок у висоту, ходьба 880 дюймів, метання молота, стрибок 3 жердиною, біг з перешкодами 120 дюймів, метання каменя масою 56 фунтів, стрибок у довжину та біг на 1 милю. Переможців визначали за мінімальною сумою зайнятих місць у кожному виді змагань [21]. У 1890-х роках деякі скандинавські народи почали запроваджувати п'ятиборство, аналогічне давньогрецькому.

Змагання 3 багатоборств не входили до програми перших двох Ігор Олімпіад сучасності. у 1904 р. у СентЛуїсі разом з Іграми III Олімпіади Асоціація американських університетів провела чемпіонат з багатобортсва.

у 1909 р. на берлінському засіданні МOK П'єр де Кубертен запропонував відродити древній пентатлон у програмі сучасних Ігор Олімпіад, до якого включив змагання 3 бігу, верхової їзди, плавання, фехтування на еспадронах та веслування [3]. У результаті обговорення програма багатоборства була скорегована: включено фехтування на шпагах та замість веслуван- ня - стрільба з пістолета. Після прийняття цього рішення Кубертен сказав: «... сучасне п'ятиборство дійсно є королем спорту». Програма була складена настільки добре, що була включена в Олімпійську хартію як обов'язковий вид олімпійської програми [10, 15]. Багато зусиль для дебюту сучасного п'ятиборства на Іграх V Олімпіади доклав голова Організаційного комітету Віктор Густав Бальк, вшановуючи давні традиції спортивних змагань шведських військових [17]. Також у Стокгольмі відбулися змагання 3 легкоатлетичного десятиборства.

у подальшому представництво спортивних багатоборств у програмі Олімпійських ігор збільшилось. На сьогодні існує багато видів змагань, де остаточний результат визначається за виступами у кількох видах спорту чи дисциплінах. На Іграх Олімпіад - це сучасне п'ятиборство, легкоатлетичні десятиборство та семиборство, тріатлон, кінне триборство, гімнастичне багатоборство, художня гімнастика, комплексне плавання, артистичне плавання, скелелазне триборство, омніум у велосипедному спорті, двоборство у важкій атлетиці, стрільба 3 малокаліберної гвинтівки 3 трьох положень, стрільба з пістолета по нерухомих цілях та по цілях, що з'являються, швидкісна стрільба з пістолета у трьох часових режимах. На зимових Олімпійських іграх - біатлон, гірське (альпійське) двоборство, лижне двоборство, скіатлон, фрігурне катання.

Зміни вимог до олімпійських видів спорту спонукає міжнародні спортивні фредерації шукати нові форми проведення змагань, які були б цікаві для глядачів. Яскравим прикладом цього процесу $є$ сучасне п'ятиборство, яке кардинально змінилось від часу свого світового дебюту на Іграх Олімпіад:

1912 р. - Офіцерське п'ятиборство - вперше представлене на Ііграх V Олімпіади

1948 р. - До участі у змаганнях допускаються цивільні

1956 р. - Система визначення результату спортсменів змінюється з суми зайнятих ними місць у кожній дисципліні на суму очок, набраних у цих дисциплінах

1962 р. - - у змаганнях з верхової їзди крос замінили на конкур

1981 р. - - Вперше проводиться чемпіонат світу серед жінок

1984 р. - Тривалість змагань скорочується до чотирьох днів з проведенням стрільби та бігу в один день; біг проводиться за системою гандикапу

1989 р. - - До програми чемпіонату світу серед чоловіків вперше включено змагання естафет

1994 р. - Зміна формату у змаганнях зі стрільби: замість вправ з малокаліберної зброї на 25 м спортсмени виконують стрільбу з пневматичної зброї на 10 м

1996 р. - 3 програми Іігор Олімпіад виключають командні змагання; змагання проводяться в один день: стрільба з пневматичного пістолета, фехтування (зі скороченням поєдинку з трьох до однієї хвилини), плавання (200 м замість 300 м), верхова їзда з перешкодами (дистанція конкуру 350-450 м замість 600 м), крос (3000 м замість 4000 м) 
2000 р. - - До програми Іігор Олімпіад включено змагання серед жінок

2009 р. - До програми змагань включено комбінований вид, який об'єднав змагання з бігу $3 \times 1000$ м та чотири серії зі стрільби по п'яти мішенях

2010 р. - Заміна стрільби з пневматичного пістолета на лазерний; проведення змішаної естафети на чемпіонаті світу; збільшення дистанції бігу з 3000 м до 3200 м $(4 \times 800$ м) у комбінованому виді

2012 р. - - У змаганнях з фехтування додається ще один етап, який проводиться за нокаут-системою

2018 р. - Змагання з усіх дисциплін проходять на одному стадіоні

У період з 1912 по 1948 р. до змагань з п'ятиборства допускалися тільки офіцери. Змагання проводились в особистій першості протягом п'яти днів: один день - один вид спорту. На Іграх Олімпіад 1912-1952 рр. місце спортсменів визначали за сумою місць, зайнятих ними у кожній дисципліні багатоборства. Починаючи 3 Ігор XVI Олімпіади 1956 р., загальний результат визначається за сумою очок, нарахованих за виступи у кожній дисципліні $[2,7]$.

Ha Іграх XV Олімпіади 1952 р. у змаганнях із сучасного п'ятиборства до особистої першості додалися командні. У 1962 р. у змаганнях з верхової їзи крос замінили на конкур. На Іграх XXIII Олімпіади 1984 р. змагання проводили у чотири дні, об'єднавши стрільбу та біг в один день. У заключній дисципліні сучасного п'ятиборства крос на 3000 м - учасники стартували за системою, аналогічною системі Гундерсена у лижному спорті: першим стартує спортсмен, який має найкращий результат за сумою чотирьох дисциплін; за ним - другий з інтервалом у часі, відповідним відставанню від лідера в очках, перерахованим в одиниці часу за таблицею оцінки результатів у кросі, далі - третій і т. д. Черговість фінішування спортсменів у кросі відповідала їх загальному місцю у сучасному п'ятиборстві.

На Іграх XXVI Олімпіади 1996 р. командний залік було виключено з програми змагань, після Ігор XXV Олімпіади 1992 р. вони стали проходити в один день у такій послідовності: стрільба 3 пневматичного пістолета, фехтування (зі скороченням поєдинку з трьох до однієї хвилини), плавання (на 200 м замість 300 м), верхова їзда з перешкодами (дистанція конкуру 350-450 м замість 600 м), крос на 3000 м замість 4000 м. Ha Iграх XXVII Олімпіади 2000 р. у змаганнях 3 сучасного п'ятиборства вперше брали участь жінки.
Після Ігор XXIX Олімпіади 2008 р. формат змагань 3 сучасного п'ятиборства докорінно змінився. Було запроваджено безпечну лазерну стрільбу, яку поєднали з бігом у фінальній частині змагань - лазер-рані. На Іграх XXXI Олімпіади 2016 р. у змаганняХ 3 фехтування на шпагах додається ще один етап - за нокаут-системою, який проходить наступного дня після змагань за круговою системою. Результат у фрехтуванні визначається за сумою очок на двох етапах. На Іграх XXXII Олімпіади 2020 р. було заплановане проведення змагань 3 сучасного п'ятиборства на Пентатлон Стадіоні, де глядачі протягом 5 год могли спостерігати за виступами спортсменів у п'яти дисциплінах з одного місця. Серед фрахівців активно обговорюється питання щодо визначення переможців за системою «чвертьфрінал - півфрінал - фінал», за якою на останньому етапі змагань олімпійські нагороди розігруватимуть вісім найкращих спортсменів [6].

Дискусія. Дослідження історичного аспекту становлення спортивних багатоборств у світі показали, що вони мають довгий шлях формування, у процесі якого з'являлось багато їх різновидів $[2,13]$. Протягом усіх періодів історії ідея різнобічної фізичної підготовки привертала увагу людства. Переможці комплексних змагань із різних видів рухової активності привертали найбільшу увагу та повагу серед учасників та глядачів змагань [19, $20,23]$. Тому з відродженням Олімпійських ігор одразу виникла ідея включити їх до програми. Першими були сучасне п'ятиборство, легкоатлетичні десятиборство та п'ятиборство [15]. Актуальним стає пошук шляхів розвитку спортивних багатоборств в олімпійському спорті як вагомого фрактора історичної спадкоємності і збереження традицій.

Спортивні багатоборства та комбіновані види змагань займають суттєве місце у видах спорту. У всіх різно- видах класифрікацій видів спорту вони мають виділятися як окрема група [3, 8]. Недоліком наявних класифрікацій $є$ ігнорування великої різноманітності комбінованих видів спорту та змагань. Спортивні багатоборства можуть бути класифріковані за такими критеріями: за приналежністю до олімпійської програми, за тривалістю, за фформою проведення, за кількістю дисциплін, за змістом, за системою визначення загального результату. Під час вивчення групи багатоборств як споріднених видів спорту слід поглиблено розглядати як загальні, так і приватні питання окремих багатоборств, виявити єдиний організуючий початок, основні напрями і тенденції розвитку.

На розвиток спортивних багатоборств впливають загальні тенденції олімпійського спорту [4], специфічні фрактори комплексності змагань $[21,22]$ та чинники окремих їх видів $[9,10,17]$. На прикладі сучасного п'ятиборства показано, як небезпека втратити статус олімпійського виду спорту через недостатню його популярність змусила МССП надати змаганням більшої динамічності та видовищності завдяки зменшенню їх тривалості, спрощенню системи визначення переможців, зрозумілої вболівальникам; локалізації місць проведення змагань; можливості спортсменів з різними провідними видами багатоборства стати переможцем; запровадженню змагань серед жінок; проведенню естасрет, у тому числі змішаних; покращенню інформаційного забезпечення проведення змагань. Кардинальні зміни формату проведення змагань відмітив президент MOK Томас Бах, яких назвав сучасне п'ятиборство одним з найбільш інноваційних видів спорту в сучасному олімпійському русі [6].

Висновки. Розвиток спортивних багатоборств слід розглядати як вагомий фрактор історичної спадкоємності і збереження традицій в олімпійському спорті, концепції фрізично розви- 
неної людини. Спортивні багатоборства та комбіновані види змагань займають суттєве місце у програмі сучасних Олімпійських ігор. Збільшення конкуренції між різними видами спорту за потрапляння до програми Олімпійських ігор спонукає представників спортивних багатоборств робити їх привабливими для комерційних структур, засобів масової інфформації та глядачів.

Перспективи подальших досліджень пов'язані 3 визначенням перспектив розвитку спортивних єдиноборств та представництва їх у програмі Олімпійських ігор з урахуванням історичної спадкоємності і збереження традицій в олімпійському спорті, з одного боку, та вимог комерційних структур, засобів масової інсформації та глядачів - 3 іншого.

Конфлікт інтересів. Автори заявляють, що відсутній будь-який конфрлікт інтересів.

\section{ЛІТЕРАТУРА}

1. Буркот КН. Современное пятиборье. Детский тренер. 2008;2:140-4.

2. Как возникло современное пятиборье. Физическая культура в школе. 2004;5:42.

3. Королев ГИ. Современная классисиикация видов спорта: науч. биогр. спорта: с древнейших времен до наших дней, от истоков - к систем. синтезу, к новым рубежам. Москва: Мир атлетов; 2008. 306 с.

4. Менеджмент подготовки спортсменов к Олимпийским играм. Бубка СН, Платонов ВН редакторы. Киев: Олимпийская литература; 2017. 480 c.

5. Павсаний. Описание Эллады. В 2 т. Пер. Кондратьева СП. 4-е изд. (Серия «Классиче- ская мысль») Москва: АСТ-Ладомир; 2002. Т.1. $496 \mathrm{c}$.

6. Панін І. «Пентатлон - стадіон» [Інтернет] Олімпійська Арена. 2020;5 12 [цитовано 2020 Трав 20]. Доступно: http://olimparena.com.ua/ puls-federatsii/887-pentatlon-stadion.

7. Папенов ЮМ. Современное пятиборье в программе Олимпийских игр. Детский тренер. 2010;3:111-5.

8. Платонов ВН. Система подготовки спортсменов в олимпийском спорте. Общая тео рия и ее практические приложения: учебник [для тренеров]. В 2 кн. Киев: Олимпийская лит 2015. Kн. 1. 680 c.

9. Современное пятиборье. Вайцеховский СМ, Широкманя Л, редакторы. Москва: Физкультура и спорт; 1969. 304 с.

10. Современное пятиборье. Вайцеховский СМ и др. Москва: Физкультура и спорт 1968. 230 c.

11. Современное пятиборье: учебник для ин-тов. физ. культуры. Варакина АП, редактор. Москва: Физкультура и спорт; 1985. 256 с.

12. Ancient Olympic Events; Pentathlon. [Internet]. Perseus digital library [updated $2020 \mathrm{Fe}$ 06]. Avalible from: http://www.perseus.tufts.edu/ Olympics/pentathlon.html.

13. Ancient Pentathlon [Internet] ModernPentathlonhttp [updated 2020 Feb 06]. Avalible from: www.perseus.tufts.edu/Olympics/pentathlon.html.

14. Apollodorus, Hard R. Apollodorus The Library of Greek Mythology. Oxford University Press; 2011: 67

15. Coubertin Pierre de. Pedagogie sportive. Nouvelle Edition. Lausanne: Bureau International de Pedagogie sportive; 1919. 158 p.

16. Gardner $P$. The Pentathlon of the Greeks Journal of Hellenic Studies. 2012; I(9): 210

17. Heck S. Von spielenden Soldaten und kämpfenden Athleten: Die Genese des Modernen Fünfkampfs. V\&R Unipress; 2013. 487 p.

18. Jackson DF. Philostratos and the pentathIon. Journal of Hellenic Studies. 1991;111:178-81.

19. Maróti E. Az antik pentathlon prob lémájához. Antik Tanulmányok. 1965; Szám 2:179 82.

20. Union Internationale de Pentathlon Moderne [Internet]. Official Website [updated $2020 \mathrm{Feb}$ 21]. Avalible from: https://www.uipmworld.org/ about-uipm.

\section{ІНФОРМАЦІЯ ПРО АВТОРІВ}

Павленко Юрій Олексійович https://orcid.org/0000-0001-7161-4163, uapavl@gmail.com Єгупов Микола Владленович https://orcid.org/0000-0001-8192-4720, iegupov1962@gmail.com Національний університет фрізичного виховання і спорту України, 03150, Київ, вул. Фізкультури, 1.

Бобр Володимир Іванович https://orcid.org/0000-0002-2143-8031, bobr@gmail.com Національний авіаційний університет м. Київ, просп. Любомира Гузара, 1

\section{INFORMATION ABOUT THE AUTHORS}

Pavlenko lurii https://orcid.org/0000-0001-7161-4163, uapavl@gmail.com Egupov Nikolay https://orcid.org/0000-0001-8192-4720, iegupov1962@gmail.com National University of Ukraine on Physical Education and Sport, 03150, Kyiv, Fizkul'tury str.

Bobr Volodimir https://orcid.org/0000-0002-2143-8031, bobr@gmail.com National Aviation University 03058, Kyiv, ave. Lubomir Husar, 1
21. Zarnowski F. All-around Men: Heroes of a Forgotten Sport. Scarecrow Press; 2005. 270 p.

22. Zarnowski F. The Decathlon: A Colorful History of Track and Field's Most Challenging Event. Leisure Press; 1989. 53 p.

23. Zarnowski F. The Pentathlon of the Ancient World. McFarland; 2013. 216 p.

\section{LITERATURE}

1. Burkot KN. Modern pentathlon. Children coach. 2008;2:140-4

2. How modern pentathlon came about. Fizkultura v shkole. 2004;5:42

3. Korolev Gl. Modern classification of sports events. Moscow: Mir atletov; 2008. 306 p.

4. Management of athlete preparation for the Olympic Games. Bubka SN, Platonov VN, editors. Kiev: Olimpiyskaya literatura; 2017. 480 p.

5.Pausanias. Description of Hellas. In 2 v. Transl. Kondratyev SP. $4^{\text {th }}$ ed. Moscow: ASTLadomir; 2002. Vol.1. 496 p.

6. Panin I. «Pentathlon - stadium» [Internet] Olympic Arena. 2020;5 12 [cited 2020 May 20] Available: http://olimparena.com.ua/puls-federatsii/887-pentatlon-stadion.

7. Papenov YM. Modern pentathlon in the Olympic Games program. Children coach. 2010:3:111-5.

8. Platonov VN. System of athletes' preparation in the Olympic sport. General theory and its practical applications: textbook in $2 \mathrm{~b}$. Kiev: Olimpiyskaya literatura; 2015. Book 1. 680 p.

9. Modern pentathlon. Vaitsekhovsky SM, Shirokmanya L, editors. Moscow: Fizkultura i sport; 1969. 304 p.

10. Modern pentathlon. Vaitsekhovsky SM et al. Moscow: Fizkultura i sport; 1968. 230 p.

11. Modern pentathlon: textbook for physical culture institutes. Varakina AP, editor. Moscow: Fizkultura i sport; 1985. $256 \mathrm{p}$

12. Ancient Olympic Events; Pentathlon. [Internet]. Perseus digital library [updated 2020 Feb 06]. Avalible from: http://www.perseus.tufts.edu/ Olympics/pentathlon.html

13. Ancient Pentathlon [Internet] ModernPentathlonhttp [updated 2020 Feb 06]. Avalible from: www.perseus.tufts.edu/Olympics/pentathlon.html.

14. Apollodorus, Hard R. Apollodorus The Library of Greek Mythology. Oxford University Press; 2011: 67

15. Coubertin Pierre de. Pedagogie sportive. Nouvelle Edition. Lausanne: Bureau International de Pedagogie sportive; 1919. 158 p.

16. Gardner P. The Pentathlon of the Greeks. Journal of Hellenic Studies. 2012; I(9): 210.

17. Heck S. Von spielenden Soldaten und kämpfenden Athleten: Die Genese des Modernen Fünfkampfs. V\&R Unipress; 2013. 487 p.

18. Jackson DF. Philostratos and the pentathIon. Journal of Hellenic Studies. 1991;111:178-81.

19. Maróti E. Az antik pentathlon problémájához. Antik Tanulmányok. 1965; Szám 2:179-82.

20. Union Internationale de Pentathlon Moderne [Internet]. Official Website [updated $2020 \mathrm{Feb}$ 21]. Avalible from: https://www.uipmworld.org/ about-uipm.

21. Zarnowski F. All-around Men: Heroes of a Forgotten Sport. Scarecrow Press; 2005. 270 p.

22. Zarnowski F. The Decathlon: A Colorful History of Track and Field's Most Challenging Event. Leisure Press; 1989. 53 p.

23. Zarnowski F. The Pentathlon of the Ancient World. McFarland; 2013. 216 p 